\title{
The Employment Court: Structure and Directions
}

\author{
T.G. Goddard *
}

This paper by the Chief Judge of the Employment Court discusses a number of aspects of the Court's operation since its establishment by the Employment Contracts Act including the nature of the work of the Court and the nature of the legal issues with which it has had to deal.

\section{Introduction}

John Foster Dulles, the United States Secretary of State around the time of the Korean War, the reputed inventor of brinkmanship or the art of making empty threats, was given to undertaking what he called agonising reappraisals of his country's foreign policy. While agonising can safely be left to others, the present is an opportunity for a descriptive reappraisal of the structure and jurisdiction of the Court. This is a particularly apt time for doing so. The work of the Court is on the increase in terms of volume of demand, and of the complexity, length and difficulty of the cases that it is called upon to hear, while the resources available have been allowed to shrink. In view of the strong emphasis in the legislation upon settlement by the parties themselves, with resort to institutional solutions being postponed for subsequent recourse only if all reasonable attempts at consensual resolution fail, it is necessary for the Court to be in a position to hear far more cases than actually go to a hearing. There is no such thing in the Employment Court as a case that is given a date of hearing but is "not reached" that day. The culture is that any date given to the parties is a fixed and actual, and not a nominal, date of hearing. The parties know that they are expected to be ready for hearing on the appointed day and, in turn, expect to be heard that day. Adjournment applications are rare and almost always made well in advance of the fixture. It is, in this climate, not generally possible to fill a gap left by a late settlement. However, Judges are not left idle as the time so rendered available can be devoted to the sooner preparation and completion of judgments in cases that have already been heard.

I have referred to the resources of the Court and their shrinkage. It is an open secret, of which all employment law practitioners are aware, that there has been, in the past five years, a concentration of resources in the Employment Tribunal which has grown exponentially in size. This is no doubt as it should be if the Tribunal is to fulfil its role as an informal body providing a speedy delivery of just solutions. Its core business is mediation and it is a high volume business. The Court by comparison has been only modestly resourced to the point where the position is now quite grave. Judicial time, already a scarce resource, has been made 
all the more so by the vacancy sadly arising on the death of the late Judge Derek Castle continuing to remain open several months later. He died unexpectedly but, before he did, it was well known that he was due to retire very shortly, so there has been no lack of time for thought to be given to his replacement. The Court has so far coped by dint of the surviving five Judges making personal sacrifices to minimise as much as humanly possible the consequences for the lead-in times before hearing and the time lapse between hearing and judgment. The Judges do not expect any accolades for putting in the additional effort that has been involved not only since Judge Castle died but also during his last illness. They have been only too pleased, as in any emergency, to see to it that the work of the Court carries on. The show must go on. However, it is not readily possible to treat a period of crisis as the norm and to count on Judges being able, on a continuous basis, to make a superhuman contribution to that work. While the vacancy remains unfilled, parties must expect to wait longer for hearings and judgments; they must realise that urgent hearings will not be able to be accommodated as soon as has been the pattern in the past; they must accept that hearings will have to be curtailed in duration to achieve an optimal throughput of cases. As part of this endeavour, the Court may need to adopt something resembling the summary judgment procedure available now for a decade in the High Court and, in more recent times, also in the District Court, under which the hearing is truncated and expedited in cases in which it can readily be shown or is evident that the defendant is unlikely to have any defence capable of succeeding.

\section{The structure of the Court}

These thoughts logically bring me to the composition of the Court. Under the statute it is required to consist of a Chief Judge and at least two other Judges'. In fact, from the time that it came into existence until November 1995 the Court has had a complement of six Judges including the Chief Judge. Since then, the Court has, following the untimely death of Judge Castle almost on the eve of his retirement, been required to function with five Judges, including the Chief Judge. This has, as I have said, put a strain on the Court's ability to deal with cases in as timely a way as was customary in the past. In particular, it has proved increasingly difficult to make allowances in the Court's calendar for the inevitable emergency applications that need to be heard and decided at once without unacceptable delays in the processing of cases following a standard timetable. I expect this trend to continue and to accelerate.

Judges are appointed by the Governor-General and their commissions of appointment continue in full force during good behaviour. ${ }^{2}$ The qualification for appointment is the usual one for judges: no person other than a barrister or solicitor of at least seven years' standing of the High Court may be appointed. ${ }^{3}$ There has been no new appointment to the Court since it came into existence in 1991. In its predecessors, appointments were generally preceded by

\footnotetext{
Employment Contracts Act 1991 (ECA), s.110.

2 ECA s.113(1), (3).

3 ECA s.113(2).
} 
rekek Castle e he did, of time for e surviving ossible the earing and ort that has They have carries or

risis as the uperhuman ect to wait be able to at hearing As part 0 judgmen also in the hich it cal capable 0

an extensive process of consultation. This notwithstanding, the Bench of the Court does not include and has never included a woman or a Maori. I have already on other occasions drawn attention to this feature and suggested that it is capable of being ameliorated.

In discussing the structure of the Court, it is necessary to notice also its formal constitution, not merely its composition and administration. In speaking of its constitution, I focus upon the kind of court that it is. It is constituted under the Employment Contracts Act 1991 as a court of record having all the powers inherent in a court of record in addition to the jurisdiction and powers specially conferred on it by statute. ${ }^{4}$ As its name implies, it is concerned with the rights, expectations, liabilities and duties of all who are affected by the employment relationship, principally employers and employees but also bargaining agents and outsiders who seek to interfere between employer and employees. In this area of the administration of justice, sole and exclusive jurisdiction for dispensing justice is vested in the Employment Tribunal and the Employment Court, with the latter being the senior institution and the ultimate arbiter in the vast majority of cases. ${ }^{5}$. The Employment Court is a court of equity and good conscience, a descendant of the ancient courts of conscience. That is its over-arching characteristic. This means that it is a court that concentrates more on fairness than on technical rules of law. Technical rules are those that could reasonably be described as rules existing for their own sake and by virtue of their own momentum, having no independent or external reason for existing (or existing in a given form) that is relevant in New Zealand and today. Equity and good conscience is a source of law as well as a technique and does not require analogies with rules of law. It is lateral thinking in the law, the only limits on doing justice being that the result produced must not be contrary to any Act of Parliament. Described shortly, equity and good conscience can be said to be a method of decision-making that seeks systematically to administer justice in a spirit of fairness, justice and right dealing and in a way that is optimally tailored to, and most apt for, the facts and circumstances of each case. Lastly, it is necessary to note that the Court is a specialist Employment Court, charged with these tasks: to oversee the role of the Employment Tribunal created by the same Act, and to deal with particular legal issues, it being recognised that the nature of employment contracts is such that the parties to them from time to time require the assistance and certainty that can be provided by a specialist court. ${ }^{6}$ The jurisdiction of the Court can therefore conveniently be classified into matters that it deals with by way of supervision of the Employment Tribunal, and matters that it deals with as a court of first instance.

\section{The Court's supervisory jurisdiction}

One of the Court's principal areas of jurisdiction is to be found in cases that come to it by way of the Employment Tribunal. Numerically the most common are appeals from adjudication decisions of the Tribunal. Any party to any proceedings before the Tribunal who

$4 \quad$ ECA s. 103

5

ECA, ss. 3 and 4.

ECA s.76(d). 
is dissatisfied with any decision of the Tribunal in the proceedings may appeal to the Court against that decision?. It is not stated whether the appeal is to be "by way of rehearing" as that is generally understood, but it is clearly not an appeal by way of de novo hearing as was the case under the Labour Relations Act 1987 within a somewhat different structure. That is made clear by s.95(4) requiring that, upon the hearing of an appeal, the Court is to consider only those issues, explanations, and facts that were placed before the Tribunal unless satisfied either that the party seeking to advance them could not, by the exercise of reasonable diligence, have placed them before the Tribunal, or that it is fair to consider them because of exceptional circumstances. This may not be as wide-ranging a restriction as appears from its language because it can only apply to grounds that were in existence at the date of the hearing before the Tribunal, and cannot operate to prevent the Court from looking at grounds coming into existence subsequently - that is to say, grounds arising from the Tribunal's treatment of the case since the hearing, or from its decision. Nevertheless, it is a serious restriction and the language is far more constrictive than was necessary merely to abolish the de novo hearing of appeals. It suggests that any point not taken before the Tribunal in the first instance may not be introduced on appeal. This is contrary to the normal practice of appellate courts which have a discretion to allow new arguments to be taken, and even to allow pleadings to be amended although that discretion would be exercised with reluctance if there is any reasonable prospect that the amendment of the pleading, if made earlier, might have affected the evidence called or the conduct of the case generally. It could not have been intended to restrict the scope of the appeal if, for example, the Employment Tribunal has decided the case on a ground that neither party relied on or even mentioned.

The scope of the Court's role as an appellate court has been worked out in a series of judgments of the Court, of which the most important are the full Court judgment in GWD Russells $v$ Muir $^{8}$ dealing with appeals generally, and the judgment of Colgan J in Deka NZ Ltd $v$ Singh $^{9}$ which had the assent of all the Judges of the Court to the statements of principle contained in it. Essentially, the position has been reached that the disadvantage of the conventional restraints that civil appellate courts have imposed on themselves has been remedied by constituting the Court to be a court of equity and good conscience. This relatively broad approach requires the Court to reconsider the material before the Tribunal and come to its own conclusions after having due regard to the Employment Tribunal's decision and the use that it has made of the advantage, not invariably or uniformly beneficial, of seeing and hearing the witnesses give their evidence.

In 1994 and 1995 the Court disposed of about 300 appeals from the Employment Tribunal. This number includes a quantity, numerically small but still important, of appeals from adjudications by the Employment Tribunal of penalty and wage recovery actions and disputes about the interpretation, application or operation of employment contracts. Nevertheless, the bulk of these appeals is from determinations of personal grievances. They represent the human rights side of the Court's jurisdiction.

7 ECA, s.95(1). 
The next most numerous category of cases emanating from the Tribunal are cases heard by the Court at first instance following their removal to the Court on application to the Tribunal or, rarely (such application having failed), pursuant to the special leave of the Court. The ground for removal is that an important question of law is likely to arise in the matter other than incidentally, or the case is of such a nature and of such urgency that it is in the public interest that it be removed immediately to the Court.

These tests have proved to be quite difficult and less than satisfactory. The Court has held that to be important, a question of law does not need to be difficult or novel or bizarre, but even that clarification does not overcome the problem where there is no important question of law involved of meeting the dual test of nature and urgency requiring removal in the public interest. One form that the conundrum has taken is where there are co-extensive proceedings in the Court and in the Tribunal or where the proceedings before the Tribunal include causes of action over which the Tribunal has no jurisdiction. In such cases the real nature of the difficulty is that there is or may be a duplication of proceedings and that, unless the case is removed, the parties will or may be put to the expense of litigating the same dispute twice once before the Employment Tribunal and once before the Court. Such a consequence is obviously to be avoided if at all possible. It was one of the weaknesses of the Labour Relations Act 1987 structure and it must be assumed that in enacting s.94 Parliament was responding to judicial criticism of precisely that situation. Thus, it may be urgent to remove a case to the Court where a case between the same parties concerning the same subject-matter but in a different format is likely to be heard by the Court before the Employment Tribunal can hear the case that is before it. However, the position is far from explicit, although tolerably clear. Some Tribunal members have adopted a robust approach, saying that they are accustomed to deciding difficult questions of law or complex factual issues, and that its concern is with the workload before it and not whatever may be before the Court. However, the Court has disapproved by and large of this kind of unicentric focus and has taken a broad overview of the work of the Employment Institutions. That still leaves a considerable number of cases in the hands of the Tribunal which do not sit well with its existence as a tribunal of the fast track. These are the cases that take two or three weeks to hear and thereafter put enormous pressure on the adjudicator to find time for considering his or her decision and hearing other cases. As time goes by, the recollection of the impact of the evidence must fade, especially of the impact of cross-examination and re-examination and any oral modifications to written briefs volunteered by the witness as they are only on tape and in such notes as the adjudicator may have been able to make.

Coming further down the frequency scale, there are two other kinds of judicial business in the Court that can be said to emanate from the Employment Tribunal. The first of these consists of the consideration of pure questions of law referred to the Court for its opinion. In referring a question of law to the Court, the Tribunal is required to state fully but concisely the material facts to which the question of law relates, and the question of law being referred ${ }^{10}$.

The remaining supervisory category is the application for review under s.105. The Court's administrative law jurisdiction is not confined to the Employment Tribunal but includes it. It also includes decisions of officers of the Tribunal and the Court, of employers, of

10 Employment Tribunal Regulations 1991, reg 22. 
employees, and their respective representatives. Because administrative law focuses upon statutory power of decision, it has been assumed in some quarters that the Employment Court's jurisdiction is limited to the Tribunal, officers of the Court and of the Tribunal, and such employers as can be said to have public law responsibilities - as, for instance, under the State Sector Act 1988. If that were so, there would be no reason for the statute to refer to the exercise of statutory powers by employees and by representatives of employees and of employers without making any distinction between private and State sectors. It is easy enough to imagine how an application for review might readily succeed as against a representative of employees who, having reached a proposed settlement on their behalf, has then frustrated the ratification procedure; or, for that matter, against an employer who, having embarked on negotiations, has, without justification or excuse, failed or refused to conduct them in good faith. There may be other examples in which applications for review could succeed against employers' or employees' representatives in respect of actions taken under or contrary to the authority of the Employment Contracts Act. However, practitioners have either found this to be a tactically unsatisfactory step or one that requires an imaginative approach of possibly uncertain outcome.

\section{The Court's original jurisdiction}

By this term I mean proceedings that begin and end in the Court without any prior history in the Employment Tribunal. The most popular areas of jurisdiction are actions by employees for damages for wrongful dismissal and actions by employers for damages for breach of contract committed by employees and others in concert with them. This is the contract-based side of the Court's jurisdiction. Its exact ambit has had to be spelled out from broad spectrum language used in the legislation. For example, the Court is given jurisdiction to hear and determine any action founded on an employment contract ${ }^{11}$. It is apparently entitled also to entertain proceedings relating to an employment contract because, in proceedings whether founded on or relating to an employment contract, the Court may (subject to one restriction) make any order that the High Court or a District Court may make under any enactment or rule of law relating to contracts. The phrase "rule of law relating to contracts" may be wider than "law of contract" and an action may be founded on or relate to an employment contract although brought in tort ${ }^{12}$ or in equity. It is necessary to note some of the Court's more express jurisdictions. They can be classified as follows:

\section{under statute}

- to hear and determine actions for injunctions, damages or compliance orders against unlawful strikes and lockouts

- to hear and determine actions for penalties within a defined scope

- within a limited scope, to make compliance orders

- to hear applications relating to harsh and oppressive contracts and, if and as appropriate, to order the setting aside of the contract wholly or in part or the payment of compensation by any party to another or both

11 Section $104(1)(\mathrm{g})$.

12 This is now in doubt. See the next footnote. 
in tort

in equity

to hear and determine proceedings founded on conspiracy, intimidation, inducement of breach of contract and unlawful means interference with trade based upon an actual or threatened unlawful strike or lockout

$\bullet$

to hear and determine applications for injunctions to prevent unlawful strikes and lockouts

\section{under common law as modified by statute}

- to hear and determine applications (in the nature of mandamus, prohibition, certiorari, declaration or injunction) for review of the exercise of certain statutory powers or statutory powers of decision

- to punish for contempt of the Court or the Employment Tribunal.

Legislation tends to be more general than specific. The general language of the Act has been found also to extend to and include:

- actions by employees for damages for wrongful dismissal

- actions by employees for damages for breaches of employment contract falling short of dismissal

- actions by employers against employees for breach of contract

- actions by employers against employees in equity for breach of confidence

- applications for injunctions in equity to protect contractual interests and status, although not involving any strike or lockout

- proceedings in equity to enforce obedience to injunctions and punish disobedience

- proceedings under s.12 of the Fair Trading Act 1986 in respect of deceptive or misleading conduct in relation to employment

- proceedings for validation, rectification, modification, vesting of property and compensation under various statutes, among them the Frustrated Contracts Act 1944, the Illegal Contracts Act 1970, the Contractual Mistakes Act 1977, the Contractual Remedies Act 1979 and the Contracts (Privity) Act 1982.

As can be seen the Court's jurisdiction may be specialised but it is by no means narrow. ${ }^{13}$

\section{Hearings before a full Court}

The jurisdiction of the Court is ordinarily exercised by a Judge sitting alone ${ }^{14}$ but the Chief Judge may direct, in relation to any proceedings, that the Court should sit as a full Court for

${ }^{13}$ For a time it was also thought to include at the suit of either employer or employee the action in tort for inducement of breach of an employment contract or unlawful means interference with such a contract, even in the absence of an actual or threatened strike or lockout. However, that view has not prevailed: see the very recent judgment of the Court of Appeal in The Conference of the Methodist Church of New Zealand $v$ Gray unreported, 24 April 1996, CA130/95.

14

ECA s.117(1). 
the hearing of those proceedings ${ }^{15}$. Under a bizarre provision, a full Court is required to consist of precisely three members, although the Court is not prevented from sitting if one of the members nominated by the Chief Judge to sit on the full Court is not present at the sitting $^{16}$. On one occasion only the quorum provision has been invoked - NZ Medical Laboratory Workers Union Inc v Capital Coast Health Ltd ${ }^{17}$.

The Act, very properly I suggest, gives no indication about when the Chief Judge should direct that the Court is to sit as a full Court. I have developed some criteria to ensure a consistent approach, the best known of which is that a full Court will generally be called for where one of the parties intends to argue that a previous decision of this Court ought not to be followed. Other criteria are too self-evident to need stating.

It is easier to develop criteria than to apply them. The Court is organised in three registries that are substantially autonomous. Each centre has resident Judges attached to it in the sense that generally that is where they sit. The statutory provision requires from the Chief Judge of the day a degree of omniscience in that, in order to direct a full Court hearing, it is first necessary to become aware that such a hearing is desirable in a particular case which may be pending in any one of the three registries.

I have put two parallel systems in place. One is contained in a practice direction ${ }^{18}$ imposing a duty on parties when they intend to invite the Court not to follow one of its previous decisions to notify that in advance to the Registrar of the Court for submission to the Chief Judge. When such notification takes place, an assessment follows, and a decision is made; obviously, it depends on how direct a challenge is made to a previous decision on whether the parties are in disagreement on the issue of the relevance of the previous decision to the present case, and on whether the challenge to the previous decision is decisive or at least central to the present case or merely peripheral to it.

The other system in place for identifying cases apt for the constitution of a full Court consists of a reporting mechanism at various stages of a case - essentially, legal information officers employed by the Employment Institutions Information Centre summarise and analyse all the cases pending before the Court as disclosed by pleadings or other documents filed. This is a time-consuming exercise because the majority of cases are run-of-the-mill, but helps to identify the need for a full Court independently of being alerted by the parties.

It needs to be mentioned that a full Court does not need to be unanimous and that, if it is not, the decision of a majority of the Judges present at the sitting constitutes the decision of the

15 ECA s.119(1).

16 ECA ss. $119(2)$ and $120(1)$.

17 [1994] 2 ERNZ 93.

18 Subsequently approved by a full Court: see GWD Russells v Muir [1993] 2 ERNZ 332. 
Court $^{19}$. Where the Judges are equally divided in opinion ${ }^{20}$ then the decision of the Court is to be the decision of the Chief Judge or, if the Chief Judge is not present, the decision of the most senior of the Judges present.

The importance of judgments of full Courts can hardly be overstated and I will later in this paper review the territory that these decisions have covered. For the moment I want to focus on only one kind of case of which there has been so far only one example. Like all courts, the Employment Court has the power to order a rehearing of a case that has already been heard and decided, subject to application being made promptly. Under standard jurisprudence, a rehearing is granted by most courts on the basis that full justice has not been done at the first hearing perhaps because of the discovery of fresh evidence or through some error of law. In the latter respect, a rehearing is an alternative remedy to an appeal on a question of law to the Court of Appeal. Where it is desired to argue that a Judge has made an error of law, it is not always easy to present such an argument to the Judge who is said to have made that error, as anyone will know who has ever had to move for a new trial in a civil action in the High Court on the ground that the trial Judge has misdirected the jury on the law. It seems reasonable therefore that an application for a rehearing should be before a full Court.

Given that a full Court can act as a court that reviews the decision of a Judge sitting alone on a rehearing, arguably there is room for it also to act as a tier of appeal. At present there is a general right of appeal from the Tribunal to the Court only, while from the Court to the Court of Appeal (in cases that originate in the Employment Tribunal) the appeal is limited to an appeal on questions of law. An argument often heard against the removal of proceedings from the Tribunal to the Court is that such will deprive the parties of their only right of general appeal. There may be something to be said in relation at least to cases that have been removed under s.94 that there should be a right of general appeal - on fact as well as on law from a single Judge of the Court to a full Bench of the Court (with or without a further right of appeal on law only to the Court of Appeal).

In any discussion of full Court decisions, it is necessary to notice two judgments of a full Court of the Labour Court which are still relevant under the Employment Contracts Act 1991. The first is NZ Labourers Union \& Ors v Fletcher Challenge Ltd \& Ors ${ }^{21}$, an important case on the legal incidents of a strike (in this case taking the form of a ban) and also authority on aspects of res judicata or issue estoppel, in particular whether findings in an application for a compliance order constitute estoppel in tort or other common law proceedings.

The second Labour Court full Court decision that is still important is the case of Tasman Pulp \& Paper $v$ NZ Shipwrights Union ${ }^{22}$ decided on the eve of the Employment Contracts Act and concerned with trade unions' widespread one-day strike (referred to as a day of action)

ECA s.120(2).

20 Which can only happen where the Court sits as a quorum of two.

$21 \quad$ [1989] 3 NZILR 129.

22 [1991] 1 ERNZ 886. 
against the passing of the Act. This case is now the standard authority on the Court's approach to applications for interim injunctions (whether involving a strike or not), and especially in those situations in which to grant an injunction or to refuse one is tantamount to giving final judgment in the case, the interim relief being interim in name only.

In the Employment Court, full Courts have also decided:

1. That the Court has jurisdiction to grant an interim injunction to restrain a dismissal with the effect of reinstating the dismissed employee pending a substantive hearing, and that this is so by virtue of its express authority under s.104(1)(g) and (h) to hear and determine any action founded on an employment contract and to make in any proceedings founded on or relating to an employment contract any order that the High Court may make under any enactment or rule of law relating to contracts: $X v Y$ and NZ Stock Exchange ${ }^{23}$.

2. That employees continuing in their employment after the expiry of a collective employment contract and so by virtue of s.19(4) of the Act employed on individual employment contracts based on the expired collective employment contract have all the rights, including collective rights, that they previously enjoyed under the expired contract: United Food and Chemical Workers Union of NZ v Talley ${ }^{24}$.

3. That because the Court has jurisdiction to entertain proceedings relating to an employment contract and not merely those founded on an employment contract, the cause of action that it may be confronted with may lie in equity or in tort: Northern Local Government Officers Union v Auckland City ${ }^{25}$. Mention was made of the English case of IBL Ltd $v$ Coussens ${ }^{26}$ an action for damages for the tort of conversion brought by a former employer against a former employee who, after the termination of his employment, had omitted to return a Rolls Royce and an Aston Martin which his employer had provided for his use. So far as I am aware nothing quite as dramatic as that has come before the Employment Court. ${ }^{27}$

23 [1992] 1 ERNZ 863.

24 [1992] 1 ERNZ 756.

25 [1992] 1 ERNZ 1109.

26 [1991] 2 All ER 133.

27 In the light of the very recent judgment of the Court of Appeal in The Conference of the Methodist Church of New Zealand v Gray, it seems unlikely that such a claim can come before the Employment Court in the future in the form of an action in tort for damages for conversion. It could still come before the Court as an action for damages for breach of contract. 
4. That the Court can apply the law of duress and undue influence: Adams $v$ Alliance Textiles $^{28}$.

5. That disclosure of documents is available in proceedings before the Employment Tribunal despite the fact that the Employment Tribunal Regulations 1991 are silent on the subject: NZ Baking Trades Union v Foodtown Supermarkets Ltd ${ }^{29}$.

6. That the duty of trust and confidence between employer and employee and the right of each to pursue personal aspirations at the expense of the other can be reconciled: Unkovich v Air NZ Ltd $^{30}$ which also confirmed that a termination of employment in breach of contract can never be justifiable.

7. The methodology that the Court uses when dealing with appeals from the Employment Tribunal and the correct principles to apply for the purpose of deciding whether a dismissal for redundancy is justifiable: GWD Russells v Muir ${ }^{3 \prime}$.

8. How the tension between an employee's duty of fidelity and the employee's freedom of expression may be reconciled: Lowe $v$ Tararua District Council ${ }^{32}$.

9. That a so-called partial lockout of employees by means of unilateral variation of their contracts while requiring them to continue to work as before is not a lockout in law and is therefore unlawful: Witehira $v$ Presbyterian Support Services (Northern) ${ }^{33}$. This case is an instance of the full Court reviewing and reversing a view of the law taken earlier by a Judge sitting alone.

10. That a balance can and must be struck between the freedom of association guaranteed by the Employment Contracts Act 1991 and the freedom of expression guaranteed by the New Zealand Bill of Rights Act 1990: NZ Medlab Workers Union Inc v Capital Coast Health Ltd $^{34}$.

[1992] 1 ERNZ 982, although the correctness of the decision was doubted obiter by the Court of Appeal in certain other respects concerned with the freedom of association. 
11. That payment of holiday pay on a pay-as-you-go basis by supplementing the hourly wage rate is a breach of the Holidays Act 1981, in the case of permanent employees at any rate: Labour Inspector $v$ Cook $^{35}$.

12. That where a proposed settlement is reached in negotiation (subject to ratification by the employees affected), ratification relates back to the point of agreement, and the other party to the settlement may not withdraw its provisionally accepted offer between agreement and ratification: NZ Engineering Union $v$ Shell Todd Oil Services $\operatorname{Ltd}^{36}$.

13. How to approach disputes concerning the interpretation, operation, and application of collective contracts: Julian $v$ Air NZ Ltd ${ }^{37}$, and Irvine $v$ Air NZ Ltd ${ }^{38}$. These cases resolved matters of importance to the aviation industry but also dealt with issues of more general importance in relation to the construction of certain kinds of employment contracts.

14. The proper construction to be placed on the Holidays Act 1981 in relation especially to statutory holidays: Gray $v$ Wellington City Mission ${ }^{39}$, and NZ Harbour Workers Union v Lyttelton Port Co Ltd ${ }^{\text {HO }}$.

15. What is the status of fixed term contracts: Smith $v$ Radio $i$ Ltd ${ }^{41}$, and Haddon $v$ Victoria University of Wellington ${ }^{12}$.

16. Whether a local authority can enter into an employment contract orally or is precluded from doing so by virtue of the Public Bodies Contracts Act 1959: Corlett v Hamilton City Council ${ }^{43}$.

While the foregoing is not an exhaustive list, it is a broad sampling of the wide range of matters arising under the Employment Contracts Act 1991 that has had the benefit of

35 [1994] 2 ERNZ 473.

36 [1994] 2 ERNZ 536.

37 [1994] 2 ERNZ 612.

38 [1994] 2 ERNZ 605.

39 [1995] 2 ERNZ 126.

40 [1995] 2 ERNZ 177.

41 [1995] 1 ERNZ 281.

42 [1995] 1 ERNZ 375.

43 [1995] 2 ERNZ 1. 
consideration by the collective minds of three Judges endeavouring, on the whole successfully, to reach and express a single view about the law and about the case before the Court. In this way in particular the Court has set about discharging its statutory function of providing certainty in employment law. The Act expressly recognises the desirability of certainty in the law. Certainty is itself a high form of justice because the operation of the law is thereby rendered predictable and those affected by it are enabled to make decisions knowing whether the steps contemplated are lawful, and if unlawful what the financial and other consequences of the illegality can be expected to be.

\section{Unresolved problems under the Employment Contracts Act 1991}

Space does not permit a full review, but only a sampling under these headings. I have chosen three topics.

\section{Freedom of association}

The freedom of employees to associate together in the furtherance of their employment interests qualifies for inclusion in the long title of the Employment Contracts Act 1991. It is not merely included but features prominently as the first necessary characteristic of an efficient labour market. It is also one of the express objects of Part I of the Act, the rest of which is quite short on specific operative provisions giving effect to these objectives. Nevertheless, they are objectives of considerable primacy. Supervision of compliance with them is entrusted to the Court along with compliance with Part V of the Act dealing with strikes and lockouts. This can be contrasted with Part II of the Act (bargaining), Part III (personal grievance), and Part IV (enforcement of employment contracts), supervision of which by way of compliance order is in the first instance with the Employment Tribunal. It is thus the Court's task to ensure in the words of the Act that no person applies "any undue influence, directly or indirectly, on any other person by reason of that other person's association, or lack of association, with employees". Applying equity and good conscience, that must be taken to be an extensive, if ill-defined, duty to protect the freedom of employees to associate with each other. Arguably, more precise definition could have been helpful. Equally, it could be said to be unreasonable to expect Parliament to have foreseen all the attacks on freedom of association that might be thought of by inventive employers seeking to advance their own best interests. Both arguments are valid. Probably the soundest view is that it is a question of degree and that some additional definition would be useful so long as it is not unduly restrictive. Again, it seems not unreasonable to have regard to the need for certainty in the law. ${ }^{44}$

This paragraph was written before the recent judgments of the Court of Appeal in NZ Fire Service Commission v Ivamy unreported, CA145/95, and Airways Corporation of NZ Ltd v NZALPA unreported, CA251/95, both delivered on 24 April 1996, but does not seem to require any modification as a result. 
The Employment Contracts Act 1991 confers on the Court a full and exclusive jurisdiction, then proceeds in a number of instances to put impediments upon its exercise by the Court. In some respects, that is understandable. Any change in policy that called for a departure from the norm of the public business transacted by the Court's predecessors needed to be signalled clearly. Section 46 uses express semaphore to prevent the Court from continuing to resort to what used to be called (not very accurately) arbitral decision-making power as a tool in the settlement of disputes arising under contracts if the matter in dispute is expressed in a contract to be capable of resolution only by the parties' agreement ${ }^{45}$. Less understandable are the restrictions contained in s.57(7) and in s 104(2). The former section is concerned with harsh and oppressive employment contracts (a term that includes contracts obtained by the use of undue influence) which can be the subject of remedies including the setting aside of the contract. Yet s.57(7) provides:

(7) Except as provided in this section, the Court shall have no jurisdiction to set aside or modify, or grant relief in respect of, any employment contract under the law relating to unfair or unconscionable bargains.

A contract that is harsh and oppressive when entered into (and so capable of being set aside) is likely to amount also to an unconscionable bargain. Conversely, if it amounts to an unfair or unconscionable bargain, it is difficult to imagine how it could fail to be harsh and oppressive, given what is needed to prove that it is the former. There are therefore few, if any, factual scenarii in which s.57(7) would operate. The restriction it contains is cosmetic.

The same cannot be said of s.104(2) which has to be read together with s.104(1)(h). In their proper order they provide:

104. Jurisdiction of Court - (1) The Court shall have jurisdiction -

(h) Subject to subsection (2) of this section, to make in any proceedings on or relating to an employment contract any order that the High Court or a District Court may make under any enactment or rule of law relating to contracts:

(2) Where the Court has under subsection (1)(h) of this section the power to make an order cancelling or varying a contract or any term of a contract, it shall, notwithstanding anything in subsection (I)(h) of this section, make such an order only if satisfied beyond a reasonable doubt that such an order should be made and that any other remedy would be inappropriate or inadequate. Appeal in Wellington Local Bodies Officers Union v Westland Catchment Board [1988] NZILR 1708 (CA). 
The tone of the provision appears to be consonant with the notion that it is for the parties to employment contracts to decide what the terms should be, not for any outside agency to do it for them. However, the parties are not infallible. Sometimes, in all innocence, one misrepresents the true position about a material fact to the other, or makes a mistake of fact or law in entering into the contract, or both parties unwittingly enter into a contract that is illegal. In all these situations, it is or may be open to the Court to modify a contract and validate it as modified, but s.104(2) apparently forbids the Court to do so whenever doing so, while seeming to be a good idea, does not appear beyond reasonable doubt to be the only solution that is appropriate or adequate. The consequences are undesirable and quite unpredictable in their impact.

It is to be hoped that Parliament will revisit this topic and remove the existing anomalies.

\section{3.}

\section{The perennial problem of the dependent contractor}

The Employment Contracts Act 1991 defines an employee as any person of any age employed by an employer to do any work for hire or reward. Neither this definition, nor that of employer, is confined to work under an employment contract (itself defined as a contract of service but as including a contract for services with a homeworker). Nevertheless, the standard view is that the jurisdiction of the Court is limited to situations where there is or has been an employment contract. There are many situations of contracts of a different but closely analogous kind, especially contracts for services under which the person doing the work is contractually or effectively tied to a single "employer" or to a small number of "employers". It seems anomalous to treat such a person as a contractor and not an employee. After all, employees are contractors too, but their contract is called an employment contract. The difference between an employee and an independent contractor is often one of label only, especially where the contractor is not in the least independent but is dependent for a fair supply of work and for fair treatment generally not so much on any contractual terms but on the good will of the "employer" and upon mutual trust and confidence. Employment-like rights for dependent contractors would not necessarily carry consequences for vicarious liability and other incidents of self-employment. There is no lack of confusion at present: it is common to hear about the treatment of the parties being different depending on whether what is at stake is the assertion of employment rights or the collection of tax. Some so-called "contractors" miss out in both respects.

\section{Procedure is power}

Civil procedure enjoys an undeserved reputation as a soporific. It is on the contrary an absorbing subject and those litigators who have a feeling for it enjoy a marked advantage over those who regard it as something of a nuisance. This may not be the time or the place for a detailed analysis of the Court's procedural rules. Their hallmarks are flexibility and efficiency, providing the parties with fair advance notice of the case each has to answer or make out and eliminating any element of unfair surprise. The procedure is constantly under review, as there is ample room for improvement. Satisfactory innovations have been pioneered in a number of areas, especially the conduct of the Court's appellate business. 


\section{Conclusion}

The Court, in the course of deciding those intractable cases that the parties are unable to settle by themselves, has developed a considered jurisprudence, intended to be consistent, from the marriage of its human rights and contract-based jurisdictions. In doing so, it has had to balance and reconcile and, where necessary, decide between, competing aspirations with due regard being paid not only to pure employment law but also to principles drawn from many other branches of the law. Moreover, regard is had not only to indigenous New Zealand laws but also, within proper limits, to the usages of the whole civilised world, the community of nations. In most cases, the Court's touchstone has been equity and good conscience. Where it has been ruled out by statute as an available approach, other judicial methodology has had to be applied. The Court has employed its procedures with a view to making the most efficient use of limited resources. It has made a concerted attempt to provide a user-friendly and cost-effective service to the extent of keeping a database of its decisions available to the public through the Employment Institutions Information Centre, and to the extent of registry officers consulting with the representatives of the parties individually before making fixtures. In return, the Court enjoys the co-operation of professional advocates who are able to see and appreciate the benefits to their clients in cost and efficiency of the Court's various procedural initiatives. 